\title{
Virtual Reality for Learning Fish Types in Kindergarten
}

\author{
https://doi.org/10.3991/ijim.v12i8.9246 \\ Gede Thadeo Angga Kusuma, I Made Agus Wirawan( $\left.{ }^{\bowtie}\right)$, I Ketut Resika Arthana \\ Universitas Pendidikan Ganesha, Bali, Indonesia \\ imade.aguswirawan@undiksha.ac.id
}

\begin{abstract}
This research aimed at developing a virtual reality based learning media application on the introduction of types of fish. The development of this application intended to facilitate the learning process in the kindergarten concerning on the introduction of aquatic animals, and specifically about fish. There were 10 types of saltwater fish and 10 types of freshwater fish which would be introduced to the kindergarten students. The development of this application is expected to attract children's learning enthusiasm about the types of fish in our environment.

The development of this virtual reality based learning media application used ADDIE model. This ADDIE model comprises of 5 stages, namely Analysis, Design, Development, Implementation, and Evaluation. With the consideration of this model, the developed product could be finalized within fine quality. It could be achieved since this model allows the developer to perform evaluation and revision during every completed stages.

The result of the user's experience testing was $89.8 \%$, indicating that this virtual reality based learning media application was considered as excellent. Therefore, this application could be used as a supporting media to introduce types of fish in the teaching and learning process conducted in the kindergarten, concerning on the theme of aquatic animals with the subtheme of fish.
\end{abstract}

Keywords—Virtual Reality, Fish Types, GoogleVR, Kindergarten, Unity 3D, Blender, Learning Media.

\section{$1 \quad$ Introduction}

Geographically, the earth has an area of approximately $70 \%$ or $2 / 3$ of the sea area compared to the land area. In more particular, Indonesia which has been well-known as the world's largest archipelago country, possess more than 17,504 islands. Its width reaches 7.7 million $\mathrm{km} 2$ consists of land ( 2.9 million $\mathrm{km} 2$ or $24.7 \%$ ) and marine waters (5.8 million $\mathrm{km} 2$ or $75.3 \%$ ) [1]. Having such a vast ocean territory, Indonesia has a diversity of flora and fauna species, which is as great as its flora and fauna that exist on land. One of the diversities of the fauna is fish.

Fish is an aquatic biota that lives in the water such as rivers, lakes, or in the oceans. This animal has become one of the human food resources due to its great economic value. In relation to its nekton nature, fish can naturally choose the water within a certain range that is suitable for its life [2]. Since its habitat is under water, it is hard for us 
to see them directly. Therefore, a technology to represent types of fish and their habitat is required. Virtual Reality is considered as an appropriate technology which offers the solution to overcome such a problem. It is a technology that allows users to interact with a computer-simulated environment, an imitated actual environment or truly an environment that exists only in the imagination. Virtual Reality technology has been widely applied in several fields such as industry, entertainment, military, education and so forth.

On 30th January 2017, the researcher conducted an observation in three kindergartens in Singaraja, namely TK Ceria Asih Singaraja, TK Ganesha, and TK Sandhy Putra Telkom Singaraja. Based on the results of the observations, it could be figured out that there were some issues in the teaching and learning process; for instance, the teaching and learning process was still conducted conventionally without having sufficient use of Information Technology (IT). Along with the advance of technology of communication and information a learning process is possible to be conducted not only in the classroom but also in anywhere and anytime [3]. More particularly, it was found on the teaching and learning process on the animal theme with the subtheme of the aquatic animal in term of types of fish. To facilitate the students' learning of the introduction of types of fish, teachers frequently used conventional learning media such as a whiteboard, props, and pictures. The implementation of Virtual Reality technology, especially for the introduction of types of fish will be effective to attract students' interest to learn since those who are at an early age have such a great curiosity. By using Virtual Reality, students will be able to figure out various shapes of fish and how the underwater environment looks clearly.

Ni Gusti Ayu Made Yeni Lestari, a lecturer of PG PAUD UNDIKSHA, confirmed that the use of Virtual Reality technology for Early Childhood education is highly applicable. At an early age, children are not able to think in an abstract manner; therefore, the use of a concrete object or media is needed to provide meaningful learning.

Based on the elaborated problems above, the researcher was interested to create a "Fish World" virtual reality-based learning media. The development of this virtual reality-based learning media is expected to attract early-age students' interest to learn, more particularly the learning process on the theme of underwater animal, i.e. fish. In relation to its development, this application is developed for Android devices by using GoogleVR SDK [4] as a Virtual Reality framework, Unity 3D [5] to build the applications thoroughly, and Blender [6] to create 3D objects.

\section{$2 \quad$ Literature Review}

\subsection{Early Childhood Education}

Kindergarten is the level of early childhood education in the form of formal education which provides educational programs for children from the age of four up to six years. Kindergarten aims to help students develop various potentials both psychic and physical that include morals and religious value, socio-emotional, cognitive, linguistic, 
physical/motor, self-reliance, and art values so that they have readiness in entering the primary education [7].

In terms of age, early childhood is a period of rapid development in various aspects, in which it potentially undergoes a continuous development. Compared to the adults, children at an early age have certain unique characteristics in which will allow them to fully grow into an adult. In this case, the child is a human being or an individual who has a particular pattern of development and needs; that is completely different from an adult [8].

In term of the learning process, early childhood education should consider the characteristics of children in each phase of their development. Therefore, an interesting media which holds the characteristics of children's development is required to facilitate play and learning activities. In this research, the case study would be conducted in TK Ceria Asih Singaraja.

\section{$2.2 \quad$ GoogleVR SDK}

Google VR SDK for Unity is a framework provided by Google to help developers create a Virtual Reality based (VR) application that is directly integrated with Unity. Unity native integration with Google VR enables the developers to build Android apps for Daydream and Cardboard with ease [4].

\subsection{Unity 3D}

Unity $3 \mathrm{D}$ is a cross-platform based game engine. Unity can be used to develop games for computers, Android-based smartphones, iPhone, PS3, and even X-BOX. Unity is an integrated tool for creating games, building architecture and simulations [5].

\section{$2.4 \quad$ Blender}

Blender is a free and open source 3D creation suite. This application supports the entire 3D pipe modeling, rigging, animation, simulation, rendering, compositing and motion tracking, even video editing and game creation [6].

\section{$3 \quad$ Metodology}

This research used the ADDIE model. ADDIE is an acronym for Analysis, Design, Development, Implementation, and Evaluation. The procedures of the development in ADDIE model consists of five stages, namely Analysis, Design, Development, Implementation, and Evaluation [9]. The stages of the ADDIE model can be seen in Figure 1. 


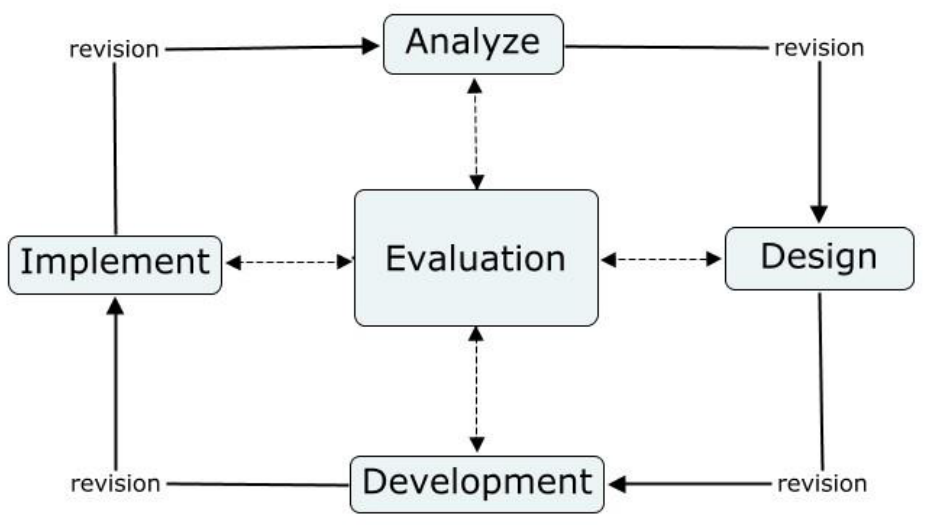

Fig. 1. ADDIE Model

\section{$4 \quad$ Results and Discussion}

This application was developed by using GoogleVR SDK framework, Unity 3D, Blender for modeling and C Sharp programming language.

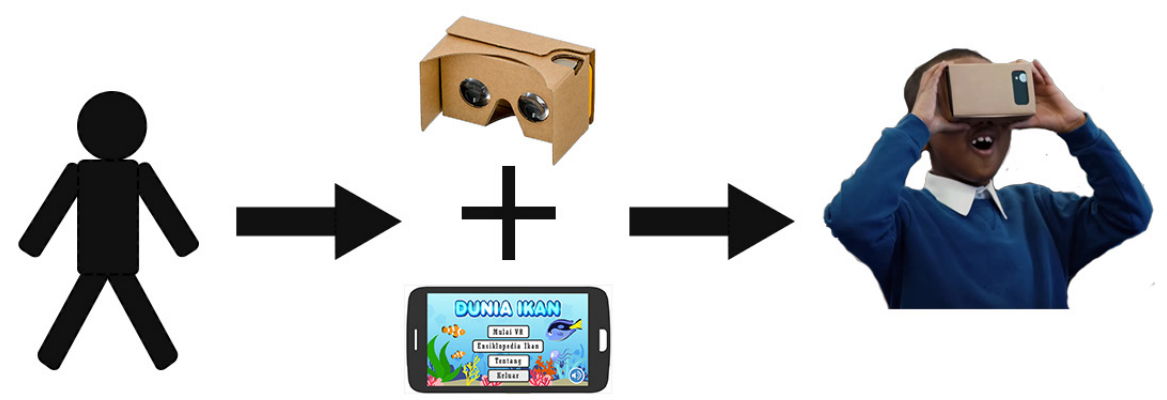

Fig. 2. The illustration of the Virtual Reality usage 1 .

\subsection{Software Architecture}

The implementation of software architecture involved GvrViewer.cs, GvrReticle.cs, MainManager.cs, SplinMove.cs, GlobalFlock.cs, MainInfo.cs, MainMenu.cs and Fish.cs. In Unity, the classes and functions were created by using C \# or C Sharp programming language with ".cs" file extension. The mappings of the implemented classes can be seen in Table 1 . 
Table 1. The mappings of the software architecture classes

\begin{tabular}{|l|l|l|}
\hline \multicolumn{1}{|c|}{$\begin{array}{c}\text { Architecture Design } \\
\text { Chart }\end{array}$} & $\begin{array}{l}\text { Process Imple- } \\
\text { mentation }\end{array}$ & \multicolumn{1}{|c|}{ The Explanation of Process Implementation } \\
\hline VR Camera & GvrViewer.cs & $\begin{array}{l}\text { The core class that forms the camera on unity into VR Camera } \\
\text { on the smartphone and has several VR Mode functions, such } \\
\text { as Distortion Correction, Screen Size, and Viewer Type. }\end{array}$ \\
\cline { 2 - 3 } & GvrReticle.cs & $\begin{array}{l}\text { This class serves to display the circle on the VR Camera so } \\
\text { that the user can interact with GameObject. }\end{array}$ \\
\hline $\begin{array}{l}\text { Main Setting Configura- } \\
\text { tion }\end{array}$ & MainPlay.cs & $\begin{array}{l}\text { This class serves to set the settings in the main scene, such as } \\
\text { Splash Text, the display for the selection of the fish object, } \\
\text { and the movement of VR Camera. }\end{array}$ \\
\hline VR Camera Movement & SplinMove.cs & $\begin{array}{l}\text { This class serves to move the VR Camera to the specified path } \\
\text { by setting the Waypoint. VR Camera will move appropriately } \\
\text { in the direction of the path, but it will stop moving if it is } \\
\text { pointing to an interactive object. }\end{array}$ \\
\hline Fish Movement & Flock.cs & $\begin{array}{l}\text { This class serves to adjust the movement of the fish and how } \\
\text { they interact with other fish. }\end{array}$ \\
\hline $\begin{array}{l}\text { Displaying the descrip- } \\
\text { tion of the fish and play- } \\
\text { ing narration }\end{array}$ & MainInfo.cs & $\begin{array}{l}\text { This class serves to display the names of the fish, the fish ob- } \\
\text { jects, descriptions, and playing the narration according to the } \\
\text { selected fish. }\end{array}$ \\
\hline $\begin{array}{l}\text { Main Menu Configura- } \\
\text { tion }\end{array}$ & MainMenu.cs & $\begin{array}{l}\text { This class serves to set the main menu, such as selecting the } \\
\text { menu, showing BGM main menu, moving the scene, and exit- } \\
\text { ing the application. }\end{array}$ \\
\hline $\begin{array}{l}\text { Displaying the name of } \\
\text { the fish }\end{array}$ & Ikan.cs & $\begin{array}{l}\text { This class serves to display the name of the fish and set the in- } \\
\text { teraction between fish with VR gaze. }\end{array}$ \\
\hline
\end{tabular}

\subsection{Implementation of User Interface}

The Splash Screen or the initial interface will begin to appear for a few seconds before entering the main menu. On its implementation, the Splash Screen was made on a theme of the sea, in which the application title, images of fish and Undiksha logo were displayed all together. The interface of the splash screen can be seen in figure 3 .

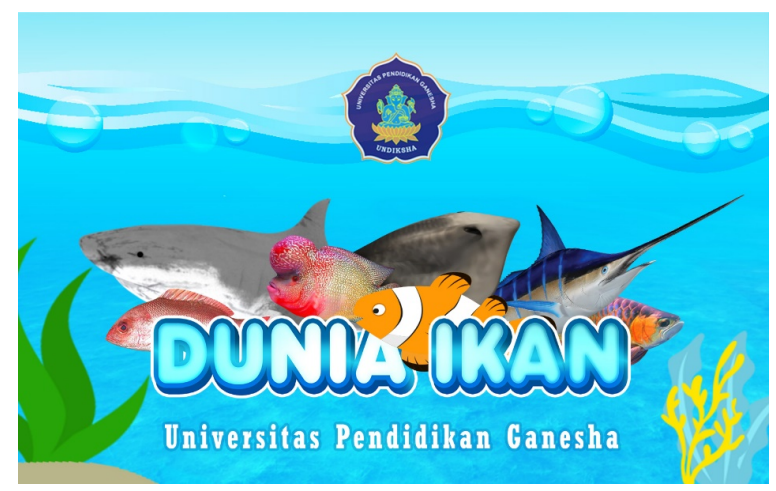

Fig. 3. Initial Interface (Splashscreen)

Main Menu appears on the screen sometime after the splash screen appears. On the main menu, there are four selection buttons that can be used for further operation. Start 
the VR button is used to start the exploration of the seabed and the introduction of types of fish. Fish Encyclopedia button serves to display the information regarding types of fish provided in this application. About button serves to display the information related to the developer. Then, Sound button serves to display the sound settings menu so that we can set the music and narration on the application. At last, the Exit button serves to exit the application. The main menu interface can be seen in figure 4 .

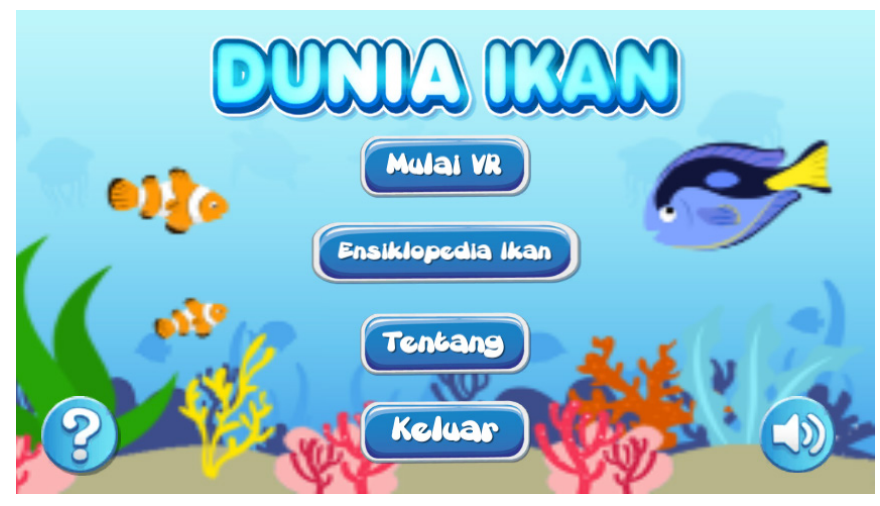

Fig. 4. The Main Menu Interface

The Implementation of Fish Encylopedia Interface. The Fish Encyclopedia is the interface when we select the Fish Encyclopedia button on the main menu. On the Fish Encyclopedia interface, the users will be displayed with the fish object, including its information at the bottom of the screen as well as the narration for the fish type. Then, the users can continue seeing the next type or the other fish by simply pressing the blue button on the right. Meanwhile, the users can press the blue button on the left if they wish to go back and to see the previous fish. Furthermore, the users can stop or replay the narration by pressing the play button at the bottom of the screen. To return to the main menu, the users can press the red back button. The Implementation of Fish Encyclopedia Interface can be seen in figure 5 .

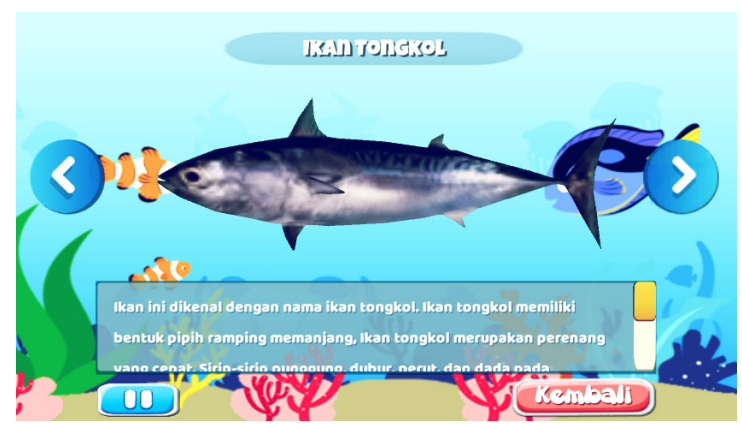

Fig. 5. Fish Encylopedia Interface 2 
The Implementation of Main Play Interface. Main Play interface is a Virtual Reality interface when we select the Start VR button and choose the types of fish, freshwater and saltwater fish. On the Main Play interface, the users will be invited to explore deep into the water to recognize various types of fish. Then, when the users point at the certain fish object, the name of the fish will be displayed. Users can see the detail information from the designated fish by pressing A button or clicking on the fish object. Afterward, they will be diverted to the Description interface. The implementation of the Main Play interface can be seen in figure 6.

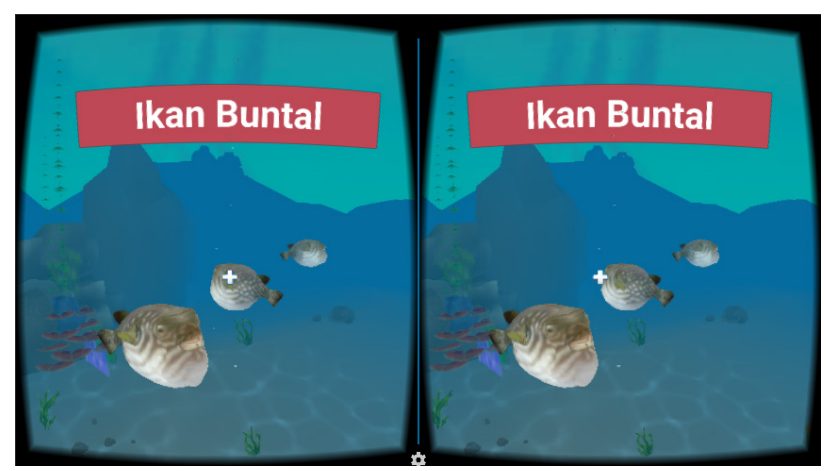

Fig. 6. Main Play Interface

The Implementation of the Fish Description. Description interface is the interface in which we choose one type of fish on Main Play. On the Description interface, the users will be presented with 3D Fish objects, a brief information about the fish, as well as the narration in Virtual Reality mode. We can return to the Main Play by pressing the Back button. The implementation of fish description interface can be seen in figure 7.

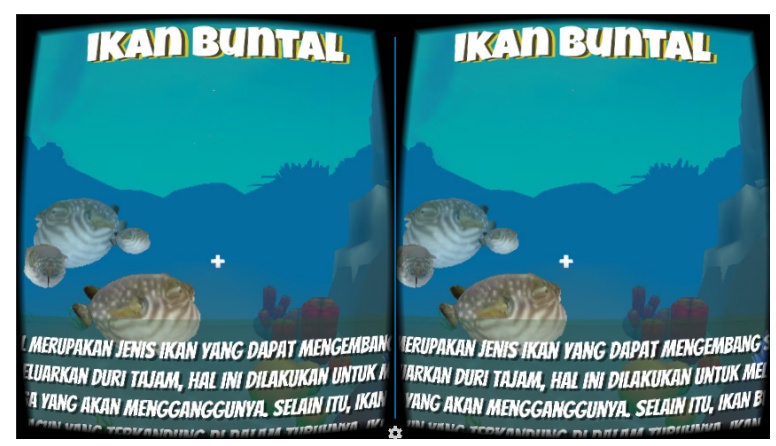

Fig. 7. The Implementation of Fish Description Interface 


\subsection{Testing}

The Blackbox testing consists of two test cases namely the truth of the process testing and applications testing on different devices. The result of the correctness test was $100 \%$, indicating that all of the processes of the application from which it was getting started until it completely exited, were working properly. Similarly, the result of the application testing on different devices was $100 \%$, meaning that all smartphones do not have any compatibility issue and manage to run this learning media application very well. Considering the results of the testing, it could be concluded that the targets had been completely achieved.

The product content testing was done by involving two content experts, Mrs. Luh Kerti S. Pd as the head of Ceria Asih kindergarten; and Ni Gusti Ayu Made Yeni Lestari S. Pd, M.Pd, a lecturer of early childhood education (PG PAUD) UNDIKSHA. Overall, the result of the assessment was $100 \%$, indicating that the material on the application has been fully compatible with the learning material in the indergarten, and is considered appropriate for children at an early age. Then, the media testing was conducted by two media experts, Nyoman Sugihartini., S. Pd, M.Pd (The first media expert); and Gede Saindra Santyadiputra., S.T., M.Cs (The second media expert). The result of media testing from the first media expert was $100 \%$. It was done for only one cycle, and then proceeded to the field testing. Meanwhile, the media testing with the second media expert was done in 2 cycles. The result of the testing in the first cycle was $86.7 \%$. The experts provided several suggestions concerning on the improvement of the application for the second cycle media testing. The media testing in the second cycle was done after revising the application by adding several statements in the instrument as suggested by the second media expert. The result of the second testing was $100 \%$, indicating that the application was getting better.

The result of user's experience testing which involved 10 respondents was $89.8 \%$, indicating that this media application was considered excellent. Product content, media, and user's experience testing were done to test the feasibility of a Virtual Reality based Learning Media Application on the Introduction of Types of Fish so that it could be used by the users later on. Since the result of the testing revealed high percentage, it could be concluded that this Virtual Reality based Learning Media Application on the Introduction of Types of Fish can be used to introduce the types of fish to the children, more particulary for the categories of both saltwater and freshwater fish.

Then, the testing was proceeded to the usability testing which was conducted by using Retrospective Think Aloud (RTA) method. In this testing, 10 respondents who were the students of Ceria Asih kindergarten in class B, were invited in turn to try this Virtual Reality based Learning Media Application on the Introduction of Types of Fish. Having done with the trial, they were asked to describe the difficulties and problems that they found while using the application. In addition, they were asked to provide their as critiques and suggestions for the application improvement. Based on the results of Retrospective Think Aloud (RTA) testing, it could be concluded that there were a few problems or difficulties which the respondents experienced in using this Virtual Reality based Learning Media Application on the Introduction of Types of Fish. Ten out of nine respondents stated that they did not find any difficulties or problems in using 
the application. Meanwhile, there was 1 respondent who found difficulties in choosing the fish category. Then, based on the critiques and suggestions as provided by 10 respondents, it could be concluded that the Virtual Reality based Learning Media Application on the Introduction of Types of Fish is considered good and interesting for children at an early age. They are really into the fish since it has attractive shapes and color variations.

\section{Conclusion}

The product content testing was done by involving two content experts, Mrs. Luh Kerti S. Pd as the head of Ceria Asih kindergarten; and Ni Gusti Ayu Made Yeni Lestari S. Pd, M.Pd, a lecturer of early childhood education (PG PAUD) UNDIKSHA. Overall, the result of the assessment was $100 \%$, indicating that the material on the application has been fully compatible with the learning material in the kindergarten, and is considered appropriate for children at an early age. Then, the media testing was conducted by two media experts, Nyoman Sugihartini., S. Pd, M.Pd (The first media expert); and Gede Saindra Santyadiputra., S.T., M.Cs (The second media expert). The result of media testing from the first media expert was $100 \%$. It was done for only one cycle and then proceeded to the field testing. Meanwhile, the media testing with the second media expert was done in 2 cycles. The result of the testing in the first cycle was $86.7 \%$. The experts provided several suggestions concerning the improvement of the application for the second cycle of media testing. The media testing in the second cycle was done after revising the application by adding several statements in the instrument as suggested by the second media expert. The result of the second testing was $100 \%$, indicating that the application was getting better.

The result of the user's experience testing which involved 10 respondents was $89.8 \%$, indicating that this media application was considered excellent. Product content, media, and user's experience testing were done to test the feasibility of a Virtual Reality-based Learning Media Application on the Introduction of Types of Fish so that it could be used by the users later on. Since the result of the testing revealed high percentage, it could be concluded that this Virtual Reality-based Learning Media Application on the Introduction of Types of Fish can be used to introduce the types of fish to the children, more particularly for the categories of both saltwater and freshwater fish.

Then, the testing has proceeded to the usability testing which was conducted by using the Retrospective Think Aloud (RTA) method. In this testing, 10 respondents who were the students of Ceria Asih kindergarten in class B, were invited in turn to try this Virtual Reality-based Learning Media Application on the Introduction of Types of Fish. Having done with the trial, they were asked to describe the difficulties and problems that they found while using the application. In addition, they were asked to provide theirs as critiques and suggestions for the application improvement. Based on the results of Retrospective Think Aloud (RTA) testing, it could be concluded that there were a few problems or difficulties which the respondents experienced in using this Virtual Reality-based Learning Media Application on the Introduction of Types of Fish. Ten out of nine respondents stated that they did not find any difficulties or problems in using 
the application. Meanwhile, there was 1 respondent who found difficulties in choosing the fish category. Then, based on the critiques and suggestions as provided by 10 respondents, it could be concluded that the Virtual Reality-based Learning Media Application on the Introduction of Types of Fish is considered good and interesting for children at an early age. They are really into the fish since it has attractive shapes and color variations.

\section{Acknowledgment}

The author would like to thank the supervisor, Ni Gusti Ayu Made Yeni Lestari S. Pd, M.Pd as the content expert; Nyoman Sugihartini., S.Pd, M.Pd and Gede Saindra Santyadiputra., ST, M.Cs as the media expert; and Luh Kerti S. Pd as the headmaster of Ceria Asih kindergarten who granted permission for the author to conduct a research in her education institution and facilitated the author in making interaction with the children.

\section{$7 \quad$ References}

[1] Kementrian Kelautan dan Perikanan Republik Indonesia, "MEMBANGUN KELAUTAN UNTUK MENGEMBALIKAN KEJAYAAN SEBAGAI NEGARA MARITIM," 2014.

[Online]. Available: http://www.ppk-kp3k.kkp.go.id/ver2/news/read/115/membangunkelautan-untuk-mengembalikan-kejayaan-sebagai-negara-maritim.html. [Accessed 6 Februari 2017].

[2] M. Fachrul, Metode Sampling Bioekologi, Jakarta: Penerbit Bumi Aksara, 2007.

[3] Wirawan, I. M. A and Paryatna, I. B. M. L, "The Development of an Android-Based Anggah-Ungguhing Balinese Language Dictionary.," nternational Journal of Interactive Mobile Technologies (iJIM), vol. 12, no. 1, pp. 4-18, 2018.

[4] Google, "Google VR SDK for Unity," 9 Februari 2017. [Online]. Available: https://developers.google.com/vr/unity/.

[5] Unity Technologies, "Getting Started," 2015. [Online]. Available: http://docs.unity3d.com/ Manual. [Accessed 17 Februari 2017].

[6] Blender Foundation, "About Blender," 2015. [Online]. Available: https://www.blender.org/ about/. [Accessed 17 Februari 2017].

[7] Depdiknas, "Standar Kompetensi Taman Kanak-kanak \& Raudhatul Athfa," Pusat Kurikulum, Badan Penelitian dan Pengembangan, Jakarta, 2003.

[8] Wahyudin, Uyu and M. Agustin, Penilaian Perkembangan Anak Usia Dini: Panduan untuk Guru, Tutor, Fasilitator, dan Pengelola Pendidikan Anak Usia Dini, Bandung: PT Refika Aditama, 2012.

[9] G. Muruganantham, "Developing of E-content package by using ADDIE Model," International Journal of Applied Research, pp. 52-54, 2015.

[10] Simarmata, Rekayasa Perangkat Lunak, Yogyakarta: Yogyakarta: Penerbit Andi, 2010.

[11] B. D. Sihite, "Pembuatan Aplikasi 3D Viewer Mobile dengan Menggunakan Teknologi Virtual Reality," JURNAL TEKNIK POMITS, Vols. Vol. 2, No. 2, pp. 397-398, 2013.

[12] E. Forest, "The ADDIE Model: Instructional Design," 2014. [Online]. Available: http://educationaltechnology.net/the-addie-model-instructional-design/. [Accessed 163 2017]. 


\section{Authors}

Gede Thadeo Angga Kusuma is a student in Department of Informatics Engeenering Education, Faculty of Engineering and Vocational, Ganesha University of Education -Indonesia (e-mail: thadeo.angga@undiksha.ac.id).

I Made Agus Wirawan is a lecturer in Department of Informatics Engeenering Education, Faculty of Engineering and Vocational, Ganesha University of Education-Indonesia (e-mail: imade.aguswirawan@undiksha.ac.id).

I Ketut Resika Arthana is a lecturer in Department of Informatics Engeenering Education, Faculty of Engineering and Vocational, Ganesha University of EducationIndonesia (e-mail: resika@undiksha.ac.id).

Article submitted 18 July 2018. Resubmitted 06 November 2018. Final acceptance 07 November 2018. Final version published as submitted by the authors. 